\title{
Effect of secochiliolide acid isolated from the Patagonian shrub Nardophyllum bryoides as active component in antifouling paints
}

\author{
Miriam Pérez $^{\text {a,b,1, Mónica García a,1 }}{ }^{\text {, }}$ Marianela Sánchez ${ }^{\mathrm{c}}$, Mirta Stupak ${ }^{\mathrm{a}, 1}$, \\ Marcia Mazzuca ${ }^{\mathrm{d}}$, Jorge A. Palermo ${ }^{\mathrm{c}}$, Guillermo Blustein ${ }^{\mathrm{a}, \mathrm{e}, *}$ \\ ${ }^{a}$ Centro de Investigación y Desarrollo en Tecnología de Pinturas - CIDEPINT, Av. 52 e/121 y 122, 1900 La Plata, Argentina \\ ${ }^{\mathrm{b}}$ Universidad Nacional de La Plata, Facultad de Ciencias Naturales y Museo, Argentina \\ ${ }^{\mathrm{C}}$ UMYMFOR, Departamento de Química Orgánica, Facultad de Ciencias Exactas y Naturales, Universidad de Buenos Aires, Ciudad Universitaria, \\ Pabellón 2, 1428 Buenos Aires, Argentina \\ ${ }^{\mathrm{d}}$ Dpto. Química, Facultad de Ciencias Naturales, Universidad Nacional de la Patagonia San Juan Bosco, Km 4, 9000 Comodoro Rivadavia, Chubut, Argentina \\ ${ }^{\mathrm{e}}$ Universidad Nacional de La Plata, Facultad de Ciencias Agrarias y Forestales, Argentina
}

\section{A R T I C L E I N F O}

\section{Article history:}

Received 13 August 2013

Received in revised form

15 January 2014

Accepted 15 January 2014

Available online 1 February 2014

\section{Keywords:}

Secochiliolide acid

Terpenoids

Nardophyllum bryoides

Soluble matrix antifouling paints

\begin{abstract}
A B S T R A C T
Environmental concerns about the use of toxic antifoulants have led to an increased interest in the development of new alternatives. So far, most of the antifouling natural products have been obtained from marine organisms. However, some secondary metabolites from terrestrial plants could be promising antifoulant candidates. The antifouling performance of secochiliolide acid, the main component isolated from Nardophyllum bryoides ethanolic extract, was evaluated for inclusion in rosin-based coatings.

Field testing was conducted during the summer months at Mar del Plata harbor, Argentina. The results indicated that secochiliolide acid-based paints completely inhibited the settlement of Bugula neritina colonies, Polydora sp., Hydroides elegans, Corophium sp. and solitary ascidians, and also reduced the attachment of some algae as Enteromorpha intestinalis and Ectocarpus sp. In addition, a lower density and diversity of microfouling species was registered.

These results highlighted the importance of terrestrial plants as a sustainable source of potential environmentally friendly antifoulants.
\end{abstract}

(c) 2014 Elsevier Ltd. All rights reserved.

\section{Introduction}

Marine biofouling of ship hulls is an age-old problem, since the surface condition of the hull is of primary importance in the performance of marine vessels. It is well established that biofouling on ships increases the surface roughness of the hull which in turn causes additional frictional resistance, reduces maneuverability and efficiency, increases fuel consumption and decreases top speed (Lewthwaite et al., 1985; Leer-Andersen and Larsson, 2003; Schultz, 2007). These combined factors result in increased fuel costs and a higher frequency of dry-docking with associated economic losses (Schultz et al., 2011). There are also possible ecological

\footnotetext{
* Corresponding author. Centro de Investigación y Desarrollo en Tecnología de Pinturas - CIDEPINT, Av. 52 e/121 y 122, 1900 La Plata, Argentina. Tel.: +54 221 4831141.

E-mail address: antifouling@cidepint.gov.ar (G. Blustein).

1 Tel.: +54221 4831141 .
}

consequences of biofouling due to the inadvertent introduction of invasive foreign species (Minchin and Gollasch, 2003; Floerl et al., 2004, 2005; Lejars et al., 2012). Many submerged structures are consequently protected by biocidal, antifouling coatings in order to minimize the effects due to the colonization of micro and macroorganisms (Evans, 1999).

Since the use of biocides in antifouling paints (in particular organotins) is becoming increasingly restricted, a significant research effort has been focused on the development of environmentally benign technologies to control fouling, of which one of the most promising is the use of non-toxic and potentially biodegradable natural products (Maréchal and Hellio, 2009; Thomas and Brooks, 2010; Blihoghe et al., 2011).

Marine benthic organisms are constantly exposed to colonization by bacterial communities and larvae of fouling organisms. Some of these organisms have developed various strategies to counteract the settlement of fouling organisms, such as the production of antifouling chemicals and/or physical defenses (Tan et al., 2010). To date, several examples of natural products with 
antifouling activity have been isolated from a variety of marine organisms, including marine bacteria, algae, seagrasses, sponges, corals, bryozoans, ascidians, etc. (Clare, 1996; Hellio et al., 2000; Rittschof, 2001; Da Gama et al., 2002; Steinberg and de Nys, 2002; Faimali et al., 2003; Angarano et al., 2007; Tsoukatou et al., 2007; Sjögren et al., 2008; Feng et al., 2009; Raveendran and Limna Mol, 2009; Villa et al., 2010; Qian and Xu, 2012; Nguyen et al., 2013). In fact, many of the natural products that have been discovered from marine organisms on the basis of their pharmacological activity may play an ecological role for their source species in the marine environment, in many cases acting as natural antifoulants. However, the production of these bioactive substances from marine sources on a large scale is a big challenge for the antifouling technology, because, to date, most of these metabolites have been isolated in low yields from delicate and slow-growing marine organisms such as corals, sponges and other invertebrates which cannot be harvested on a commercial scale without environmental harm (Rittschof, 2001). Mariculture of these marine invertebrates is not an easy task, and under different environmental conditions the production of bioactive metabolites may vary substantially. All these issues pose an almost unsolvable sustainability problem for the large-scale production of natural antifoulants of marine origin.

For this reason, an additional effort has to be made in the search of natural antifoulants from more sustainable resources such as abundant and easy collectable terrestrial plants. Comparatively little attention has been given to terrestrial plants in the search for natural products which may act as antifoulants, and only a few antifouling compounds have been reported from these sources (Yamashita et al., 1989; Hyodo et al., 1992; Sawant and Wagh, 1994; Sawant et al., 1995; Göransson et al., 2004; Angarano et al., 2007; Pérez et al., 2007; Chen et al., 2008; Zhou et al., 2009; Ovesen et al., 2011). Plant natural products from abundant and widely distributed species represent an attractive and sustainable source of new bioactive compounds. Terrestrial plants produce secondary metabolites that exhibit a variety of biological activities, many of which are of considerable significance to humans (Sánchez et al., 2010). It is worth noting that some plant extracts have shown antifouling activity, e.g. Quercus dentate (Yamashita et al., 1989), Xanthium strumarium (Harada et al., 1985), Eucalyptus resinifera (Hyodo et al., 1992), Eucalyptus grandis (Singh et al., 1996), Eucalyptus rubida (Yamashita et al., 1986) and Zingiber officinale (Etoh et al., 2002) on mussel byssal thread formation, Acacia pennata and Barringtonia acutangula on some diatoms and invertebrates (Sawant and Wagh, 1997), Schinopsis sp. tannin and tannate (Stupak et al., 2003; Pérez et al., 2007; Blustein et al., 2009) and some Chinese herbs on barnacle settlement (Feng et al., 2009). Additionally, some common plants as Capsicum sp. (pepper), Allium sp. (onion) and Derris scandens (hog creeper) restrain the attachment of cirripede larvae and bacteria or inhibit their growth (Sawant et al., 1995; Xu et al., 2005a,b; Lin et al., 2009). This is no surprise, considering the abundance of antibiotic or cytotoxic secondary metabolites in plant extracts that could affect either biofilm formation as the settlement of larvae.

In this context, Nardophyllum bryoides (Chiliotricum group, Asteraceae), a widely distributed shrub in Argentinean and Chilean Patagonia and the Andes (Jakupovic et al., 1986; Bonifacino, 2005) was selected to evaluate its possible antifouling activity. In previous studies, some metabolites isolated from this species have shown moderate cytotoxic activity against human pancreatic adenocarcinoma cell lines (Sánchez et al., 2010) and strong trypanocidal effect (Siless et al., 2013). Also, the extracts from another species of this genus, Nardophyllum armatum, showed antioxidant, antibacterial, antirheumatic and antifungal activity. In addition, digestive, antitussive and febrifuge properties have been reported for this species (D'Almeida et al., 2007; Barboza et al., 2009; D’Almeida et al., 2011).

The crude ethanolic extract of $N$. bryoides was included in the formulation of a soluble-matrix antifouling paint, which was tested in field trials in Mar del Plata harbor. In this type of paints, water diffusion within the matrix could dissolve any water-soluble components and lead to (i) the diffusion of active species out of the coating (release) and/or (ii) the dissolution of the soluble-matrix paint by the slightly alkaline $\mathrm{pH}$ of seawater (erosion). These two mechanisms lead to the release of bioactive species and the renewal of the surface, respectively (Lejars et al., 2012). The release rate of insoluble active molecules from soluble-matrix paints is often controlled by the erosion rate of the immersed coating. The promising results obtained with the paint containing the crude extract of $N$. bryoides led us to also test an enriched fraction of this extract, and finally to the identification of secochiliolide acid (1), the main component of the extract, as a promising antifouling substance.

\section{Material and methods}

\subsection{General experimental procedures for extraction and isolation}

Solvents were distilled for chromatography. NMR spectra were recorded on Bruker AC-200 (200.13 MHz) and Bruker Avance II $(500.13 \mathrm{MHz})$ spectrometers, using the signals of residual nondeuterated solvents as an internal reference. All 2D NMR experiments (COSY, DEPT-HSQC, HMBC, and NOESY) were performed using standard pulse sequences. HRMS were acquired on a Bruker micrOTOF-Q II spectrometer. TLC was carried out on Merck Sílicagel 60 F254 plates. TLC plates were sprayed with $2 \%$ vanillin in concentrated $\mathrm{H}_{2} \mathrm{SO}_{4}$. Merck Silicagel (230-400 mesh) was used for column chromatography. Sephadex LH-20 was obtained from Pharmacia Inc.

\subsection{Plant material}

Specimens of $N$. bryoides were collected at Departamento de Escalante, Province of Chubut (Argentina), in February 2008 (summer). A voucher specimen (HRP6865) was identified by María Elena Arce (Universidad Nacional de la Patagonia San Juan Bosco, Argentina) and was stored at the Herbario Regional Patagónico, Universidad Nacional de la Patagonia San Juan Bosco.

\subsection{Extraction, fractionation and compound identification}

Ground aerial parts of fresh plant material (1000 g) were extracted exhaustively with ethanol ( 3 times, $24 \mathrm{~h}$ each) at room temperature $\left(20 \pm 1{ }^{\circ} \mathrm{C}\right)$, and the extract was evaporated at reduced pressure to yield a syrupy residue ( $90 \mathrm{~g}$ ). This residue was partitioned between $\mathrm{MeOH}: \mathrm{H}_{2} \mathrm{O}$ (9:1) and cyclohexane. The yield of polar subextract was $5.8 \mathrm{~g}$ per $100 \mathrm{~g}$ of fresh plant material. The polar subextract (NOP) was chosen for the experiments because, by preliminary chromatographic analysis, it had a higher content of secondary metabolites with the presence of some major components. In contrast, the lipophilic subextract (NOL) showed no major components and, by chromatographic and spectroscopic inspection (NMR), was not interesting from a chemical point of view. The polar subextract (NOP) was concentrated to an aqueous suspension and then partitioned between EtOAc and 10\% aqueous $\mathrm{NaOH}$. The basic aqueous phase was then acidified $(\mathrm{pH}=3$ ) by addition of $2 \mathrm{M} \mathrm{HCl}$, and extracted three times with EtOAc. This last organic phase was evaporated up to dryness, giving an acidic component-enriched fraction (NOPab). Chromatographic and spectroscopic inspection 
(NMR) of NOPab indicated the presence of a major terpenoidal compound and a mixture of flavonoids. NOPab was redissolved in a small volume of $\mathrm{MeOH}$ and permeated through a Sephadex LH-20 column $(2 \times 50 \mathrm{~cm})$ using $\mathrm{MeOH}$ as eluant. The fractions that contained the major terpenoidal compound were pooled, and finally purified by vacuum flash chromatography on silicagel, to yield $4.32 \mathrm{~g}$ of pure compound 1 (4.8\% yield from the crude ethanolic extract, $7.5 \%$ from NOP) which was identified by spectroscopic analysis (1D and 2D NMR, MS) as secochiliolide acid, which we previously isolated from the same plant.

Secochiliolide acid (1): oil, $\mathrm{ESI}^{+} \mathrm{HRMS}(\mathrm{m} / z): 347.1858[\mathrm{M}+\mathrm{H}]^{+}$ (Calcd. $\mathrm{C}_{20} \mathrm{H}_{27} \mathrm{O}_{5}^{+}$: 347,1853; err: 0,500 ppm); $364.2126\left[\mathrm{M}+\mathrm{NH}_{4}\right]^{+}$ (Calcd. $\mathrm{C}_{20} \mathrm{H}_{30} \mathrm{NO}_{5}^{+}$: 364,2118; err: $0.78 \mathrm{ppm}$ ); 369.16732[M $\left.+\mathrm{Na}\right]^{+}$ (Calcd. $\mathrm{C}_{20} \mathrm{H}_{26} \mathrm{NaO}_{5}^{+}$: 369,1672; err: -2.3 ppm); 715.3457 $[2 \mathrm{M}+\mathrm{Na}]^{+}$(Calcd. $\mathrm{C}_{40} \mathrm{H}_{52} \mathrm{NaO}_{10}^{+}$: 715,3453; err: $\left.0.41 \mathrm{ppm}\right) .{ }^{1} \mathrm{H}$ NMR $\left(500 \mathrm{MHz}, \mathrm{CDCl}_{3}\right) \delta 7.47(\mathrm{br} \mathrm{t}, J=0.6 \mathrm{~Hz}, \mathrm{H}-16), 7.42(\mathrm{t}, J=1.7 \mathrm{~Hz}, \mathrm{H}-$ 15), 6.41 (dd, $J=1.7,0.6 \mathrm{~Hz}, \mathrm{H}-14$ ), 5.37 (dd, $J=10.5,6.0 \mathrm{~Hz}, \mathrm{H}-12$ ), 2.92 (dd, $J=11.6,3.1 \mathrm{~Hz}, \mathrm{H}-10), 2.46$ (dd, $J=13.0,6.0 \mathrm{~Hz}, \mathrm{H}-11 \mathrm{a})$, 2.43 (br t, $J=5.6 \mathrm{~Hz}, \mathrm{H}-6 \mathrm{a}), 2.22$ (m, H-2), 2.17 (H-6b), 2.12 (H-1a), 2.04 (H1b), 2.02 (H-11b), 1.73 (d, $J=1.0 \mathrm{~Hz}, \mathrm{H}-19), 1.72$ (H-7a), 1.72 $(\mathrm{H}-8), 1.71$ (d, $J=1.8 \mathrm{~Hz}, \mathrm{H}-18), 1.51(\mathrm{H}-7), 1.33$ (d, $J=6.7 \mathrm{~Hz}, \mathrm{H}-17)$. ${ }^{13} \mathrm{C}$ NMR $\left(125 \mathrm{MHz}, \mathrm{CDCl}_{3}\right) \delta 179.6(\mathrm{C}-3), 177.4(\mathrm{C}-20), 144.0(\mathrm{C}-15)$, 140.2 (C-16), 128.3 (C-5), 128.1 (C-4), 124.4 (C-13), 108.6 (C-14), 70.7 (C-12), 52.1 (C-9), 45.2 (C-11), 41.6 (C-10), 36.4 (C-8), 32.7 (C-2), 29.6 (C-7), 26.0 (C-1), 21.6 (C-6), 20.9 (C-18), 20.6 (C-19), 16.0 (C-17).

\subsection{Soluble matrix paints - general procedure}

Soluble matrix antifouling paints were prepared by dissolution of rosin (film forming) and oleic acid (plasticizer) in a xylene/white spirit mixture (1:1) using a high-speed disperser. A laboratory scale ball mill was loaded with this mixture ('vehicle') and pigments (zinc oxide and calcium carbonate), and dispersed for $24 \mathrm{~h}$ (Table 1). Then, paints were filtered and fractionated in portions, one of which was used as a negative control and the remaining as treatments. Pigment volume concentration (PVC) was $45 \%$ for all paints tested. The average particle's size of the pigment was $0.21 \mu \mathrm{m}$ for zinc oxide (Oxido Metal S.A) and $1.8 \mu \mathrm{m}$ for calcium carbonate (Camuati S.A.I.C). For treatments, the polar subextract (NOP), the acidic compounds from NOP (NOPab) and the main compound from NOPab (MC) were incorporated in matrix paints. Finally, paints were dispersed during $1 \mathrm{~h}$.

\subsection{Field trials}

Sandblasted acrylic tiles $(4 \times 12 \mathrm{~cm})$ were used for field trials. Paints were applied by brush on tiles previously degreased with toluene. Four coats of paint were applied and allowed to dry for $24 \mathrm{~h}$ between each application, resulting in a final dry thickness of $75 \pm 5 \mu \mathrm{m}$. Coated panels were submerged in a marina in Mar del Plata harbor (Argentina) $\left(38^{\circ} 02^{\prime} 30^{\prime \prime} \mathrm{S}-57^{\circ} 32^{\prime} 00^{\prime \prime} \mathrm{W}\right)$. Also, paints without the addition of natural extracts and unpainted acrylic tiles were simultaneously submerged. All tests were performed in triplicate.

Table 1

Base paint composition.

\begin{tabular}{lr}
\hline Components & $\% \mathrm{~V} / \mathrm{V}$ \\
\hline Zinc oxide & 16.2 \\
Calcium carbonate & 10.8 \\
Rosin & 27.0 \\
Oleic acid & 6.0 \\
Xylene/white spirit $(1: 1)$ & 40.0 \\
\hline
\end{tabular}

Abundance percentages for each species of fouling settled on panels were estimated with a grid after 45 days exposure in the sea (January/February). Settlement of micro and macrofouling organisms was estimated as percentage cover on each plate using a dotgrid estimate method (Foster et al., 1991). In this latitude, the fouling community is characterized by a marked seasonal pattern, with heavy species recruitment during summer months (December-March). For this reason, experiments were carried out in two consecutive years, starting with the study of the activity of the polar extract in the first year, and of fractions and the major component during the second year. Thus, the treatments tested during the first year were: unpainted control panels (T1), painted control panels (paint without antifouling compounds) (T2) and painted panels with $1 \%$ Wt NOP (T3). For the second year it were evaluated the following treatments: unpainted control panels (T4), painted control panels (paint without antifouling compounds) (T5), painted panels with $1 \%$ Wt NOPab (T6) and painted panels with $0.03 \%$ Wt MC (T7).

\subsection{Statistical analysis}

All statistical analyses were performed with SPSS software. The normality assumption was verified with the Shapiro-Wilk's test (Shapiro and Wilk, 1965) and variance homogeneity with Levene's test. The differences between treatments and control were determined by one-way analysis of variance (ANOVA) followed by Tukey post hoc test. Differences were considered to be significant at $p<0.05$.

\section{Results}

The main compound (MC) found in NOPab was the diterpene secochiliolide acid (Fig. 1). Several flavonoids were detected in NOPab as minor components, while some previously identified pentacyclic triterpenes remained in the minor neutral residual fraction of NOP, obtained during the original basic extraction.

After an exposure period in Mar el Plata harbor, paints containing NOP, NOPab and MC showed strong antifouling effect on conspicuous species of the fouling community (Figs. 2 and 3).

During the first year of experiments the macrofouling community on both unpainted control and negative control panels (T1 and T2) was dominated by colonial ascidians (Botryllus spp.), bryozoans (mainly Bugula neritina and Bowerbankia sp.), mudbuilder tubes Corophium sp. and algae (Enteromorpha intestinalis and Ectocarpus sp.). ANOVA test revealed that there were significant differences between treated and control panels $(p<0.05)$. Paints containing NOP (T3) caused a reduction in the amount of fouling and also in species diversity. These paints completely inhibited the settlement of $B$. neritina and tube building species as Spirorbis sp. and Polydora sp. and reduced significantly the attachment of E. intestinalis, Botryllus sp. and Corophium sp. (Fig. 4). On the other hand, microfouling was also affected by the extract, particularly the settlement of Melosira sp. and Grammatophora sp. In contrast, no differences between treated and control panels was observed in the settlement of Nitzschia longissima (Fig. 5).

During the second year of experiments NOPab-paints and MCpaints were simultaneously studied, and after immersion time in the sea, both soluble matrix paints exhibited low fouling attachment. Statistical analysis showed significant differences between treatments and controls (T4 and T5) $(p<0.005)$ although there were no differences between NOPab-paints (T6) and MC-paints (T7) (Fig. 2).

The antifouling activity of T6 and T7 was potent against the main fouling organisms. B. neritina colonies, Polydora sp., Hydroides 


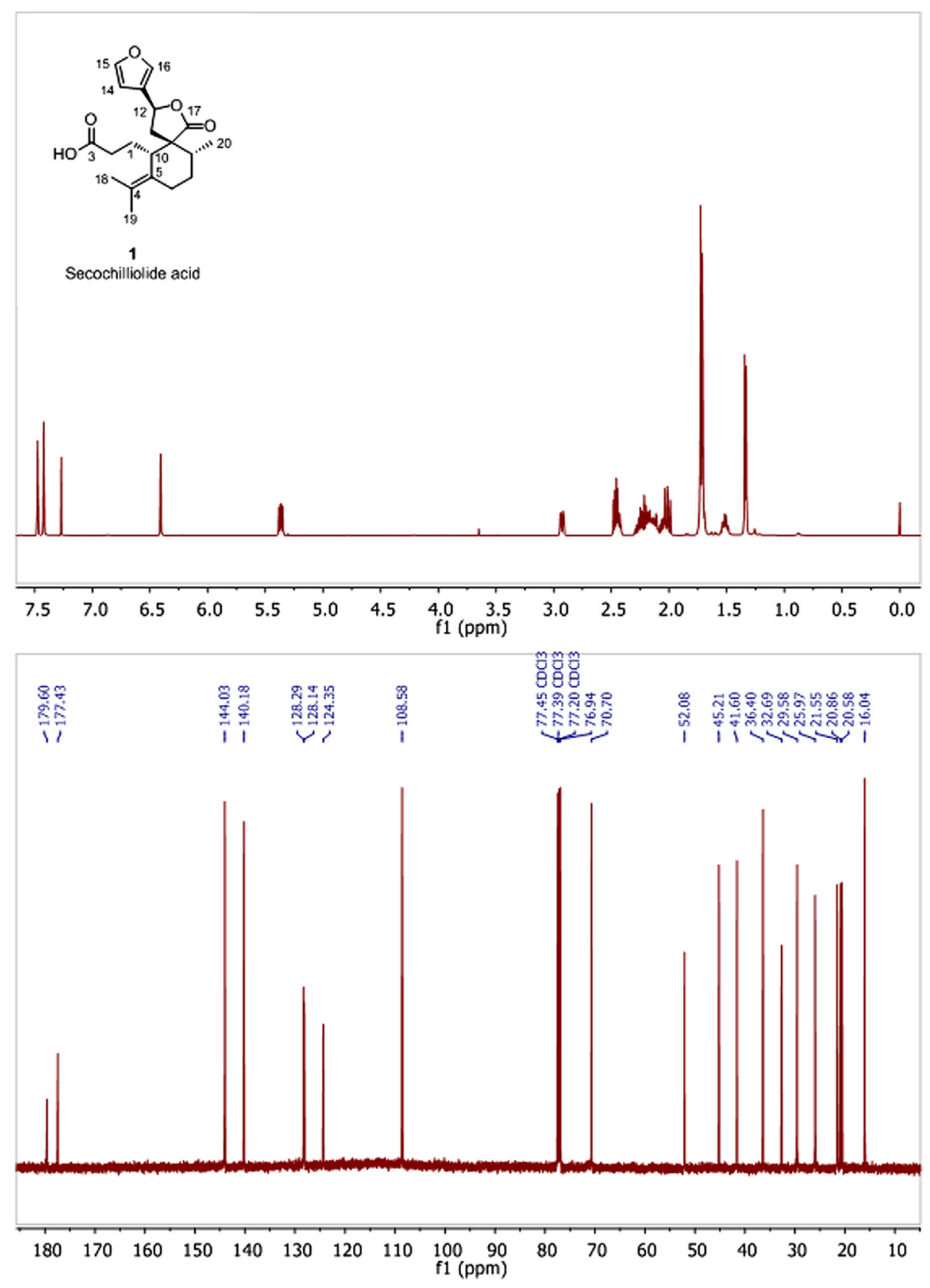

Fig. 1. Secochilliolide acid structure, ${ }^{1} \mathrm{H}$ NMR $\left(\mathrm{CDCl}_{3}, 500 \mathrm{MHz}\right)$ and ${ }^{13} \mathrm{C} \mathrm{NMR}\left(\mathrm{CDCl}_{3}, 125 \mathrm{MHz}\right)$ spectra.

elegans, Corophium sp., while solitary ascidians were completely inhibited by these paints. Also, the settlement of $E$. intestinalis and Ectocarpus sp. algae was diminished (Fig. 6).

Both treatments, T6 and T7 had successful performances, albeit some differences in two directions were observed. On the panels coated with NOPab, Ectocarpus sp. was more common on plates coated with the secochiliolide acid-containing paint and, conversely, colonial ascidians were observed on T7 panels, but were virtually absent on T6 panels (Fig. 6).

Microfouling settlement was characterized by a low density and diversity of organisms. T6 and T7 inhibited several common diatoms as Nitszchia sp., Melosira sp., Pleurosigma sp. and Thalassiotrix sp. and significantly reduced Navicula sp. abundance. However, $N$. longissima was not affected by these formulations (Fig. 7).

\section{Discussion}

Problems associated with tin and copper antifouling compounds have highlighted the need to develop new environmentallyfriendly antifouling coatings. A wide range of chemicals have been used as antifouling biocides, displaying very different physico-chemical properties and therefore differing environmental fates, behavior and effects. In order to be considered a strong candidate for use as an antifouling agent, the water solubility of a bioactive compound should be low enough to ensure that it will be released from paints at a constant rate. Low water-solubility also ensures a low diffusion rate along the water column, which allows the establishment of a stable, relatively higher concentration of the biocide near the protected surface. It is no surprise then, that most of the wealth of natural antifouling substances produced by 


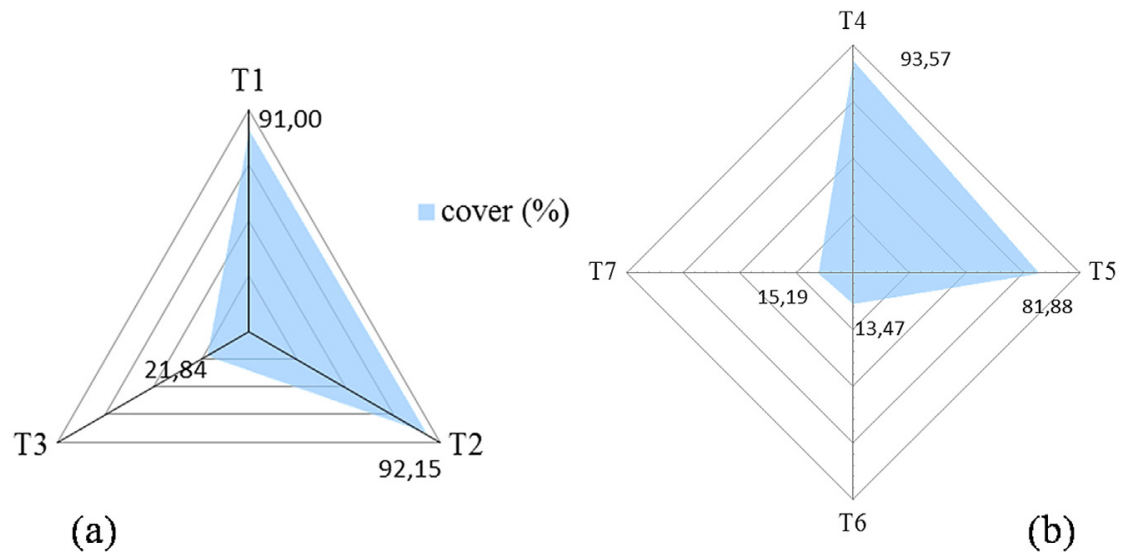

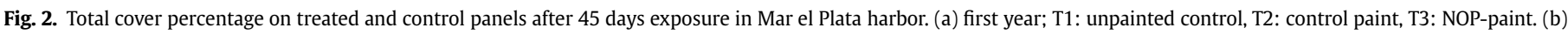
second year; T4: unpainted control, T5: control paint, T6: NOPab-paint, T7: MC-paint.

sponges and other marine invertebrates are compounds with very low water-solubility. For these reasons the search for antifouling natural substances is oriented towards organic extracts of organisms rather than aqueous extracts. The typical isolation process of natural antifouling substances usually begins with the identification of bioactive natural extracts, followed by bioassay-guided fractionation, usually helped by chromatographic and spectroscopic analysis of the fractions until the final isolation and identification of the bioactive compound(s), much the same as in the search for compounds with pharmacological interest.

Based on the previously described problems associated with the sustainability of natural antifoulants of marine origin, the focus of this study was set in the search of a plant extract, or a plant-derived natural product which could be incorporated as active component in an antifouling paint. In this context, recent laboratory experiments employing terrestrial plant extracts detected antimicrobial properties in coconut husk fiber extracts (Viju et al., 2013) and also the production of cyclotides (small proteins) from Rubiaceae and Violaceae with reversible, nontoxic, antisettlement effects on the barnacle Balanus improvisus (Göransson et al., 2004; Ovesen et al., 2011).

The focus of this research was a search for a plant extract that could meet some of the following criteria: a) abundant and easy to collect (without ecological harm) natural source, b) chemical richness, in terms of the presence of major secondary metabolites, and c) if possible, previous bioactivity studies which may be related to a possible antifouling action, such as antibiotic activity or cytotoxicity. Incorporation of such an extract as active component in a marine coating would enable field tests in which the performance of the extract would be simultaneously tested against the whole fouling community of the test site. On the other hand, it will test the potential use as additive of the extract as a whole, without the need of purification steps.

A plant species which met the above mentioned criteria was the Patagonian shrub Nardophyllum bryoides. This species grows profusely on the arid Patagonian plateau in Argentina, under harsh conditions (low rain, strong winds, extreme temperature amplitudes), and is relatively easy to collect. The chemical composition of $N$. bryoides has been studied only recently, and the biological and pharmacological activities of its extract and chemical components are just being untapped. This plant produces a large amount of organic extract, which is particularly rich in secochiliolide acid, a very interesting diterpenoid that can be easily isolated in fairly large quantities ( $2-3 \mathrm{~g} / \mathrm{kg}$ of fresh aerial parts). This substance has shown moderate cytotoxicity (Sánchez et al., 2010) as well as potent trypanocidal action (Siless et al., 2013). All these factors made the extract of $N$. bryoides an ideal candidate to test for antifouling activity.
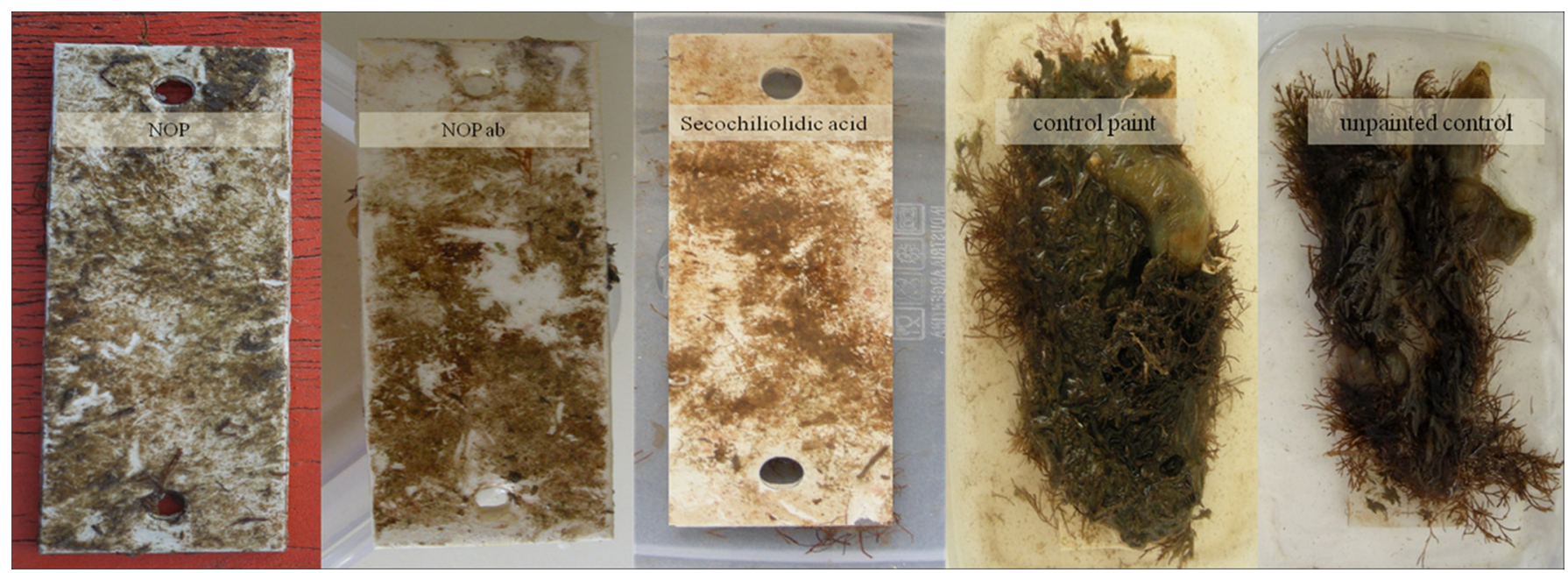

Fig. 3. Painted panels after immersion time. 


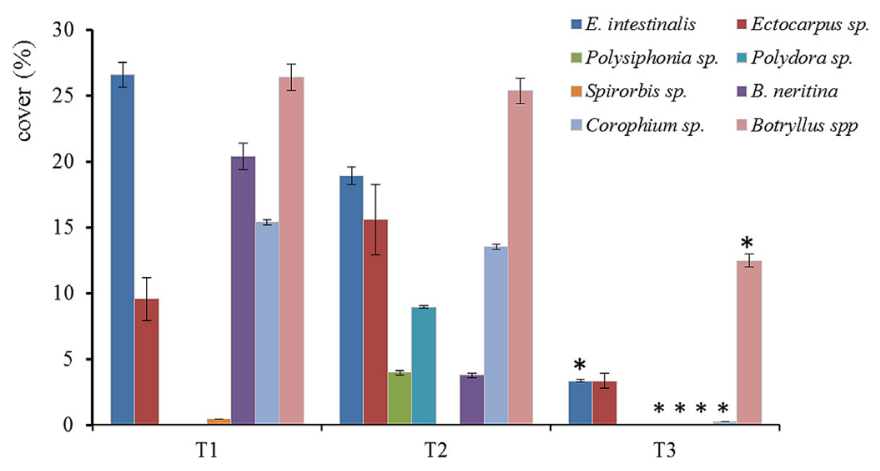

Fig. 4. Macrofouling percentage cover on painted panels vs. controls, 45 days exposure (first year). T1: unpainted control, T2: control paint, T3: NOP-paint. Bars $=$ mean $\pm \mathrm{SE}$; *significant differences from controls $(p<0.05)$.

The initial ethanolic extract was partitioned between $\mathrm{MeOH}$ : $\mathrm{H}_{2} \mathrm{O}(9: 1)$ and cyclohexane to yield lipophylic (NOL) and polar (NOP) subextracts. Based on previous chemical investigation of this species, NOL was discarded since it consisted mainly of fats and waxes, and did not contain bioactive components. NOP was incorporated in soluble-matrix paint and tested in the Mar del Plata harbor during the summer period, with promising results. The initial finding of antifouling activity in the polar subextract of this species, prompted us to try a further fractionation to get insight on the nature of the active substances. Plant extracts are complex mixtures of several classes of compounds, with different bioactivities. For example, some of the components may have antibiotic activity, while others can be cytotoxic. For this reason, the activity of a crude extract as a whole may differ from the activity of the obtained fractions, since in the fractionation process, substances are sorted out based on their chemical or structural properties, such as polarity, hydrophobicity, acid-base character, etc.

Previous knowledge on the chemical composition of NOP dictated that an acid-base extraction would be profitable since the main components were acidic. Besides secochiliolide acid, NOP had other classes of compounds such as flavonoids (acidic) and some minor neutral pentacyclic triterpenoids. For this reason, NOP was extracted with aqueous base to yield a major acidic fraction (NOPab) and a very minor neutral fraction. The initial hypothesis that the main, acidic components of the extract were responsible for the observed bioactivity was rewarded, since NOPab retained the antifouling activity initially observed in NOP. The pentacyclic triterpenoids of NOP, which lack acidic groups, were not extracted

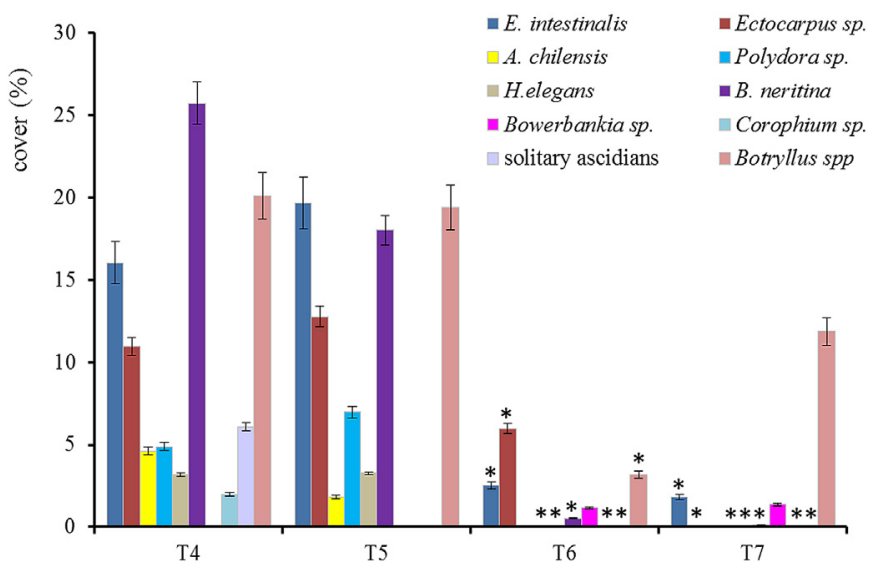

Fig. 6. Macrofouling percentage cover on painted panels vs. controls, 45 days exposure (second year). T4: unpainted control, T5: control paint, T6: NOPab-paint, T7: MC-paint. Bars $=$ mean \pm SE; *significant differences $(p<0.05)$.

by the aqueous basic solution and for that reason were not present in NOPab, and obviously played no part in the antifouling activity exhibited by this fraction. Secochiliolide acid (1) was purified, incorporated into soluble-matrix paint (MC), and tested in parallel with NOPab paint in the sea. As for the flavonoids present in NOPab, they were not used in the experiments because these compounds are ubiquitous in the plant kingdom, and have well known properties, which include antifouling activity.

In earlier investigations, the antifouling effect of flavonoids on the barnacle Balanus amphitrite was confirmed (Zhou et al., 2009), a repellent effect of flavonoids from the bark of Prunus jamasakura on the blue mussel Mytilus edulis (Takasawa et al., 1990; Yoshioka et al., 1990), and on other fouling organisms (Brango Vanegas, 2011; Gavin and Durako, 2011; Iyapparaj et al., 2012). Our interest was instead focused on secochiliolide acid which is a major and easy-topurify component of the extract.

The results indicated that inhibition of organism settlement by $N$. bryoides polar subextract (NOP) was due mainly to secochiliolide acid; the present studies add a new potential use to this compound as an antifoulant because it showed inhibition settlement on most conspicuous fouling species at Mar del Plata harbor. Secochiliolide acid demonstrated strong antifouling activity on most of the micro and macrofouling species, except for Botryllus sp. However, NOPab coating did inhibit the attachment of this colonial ascidian suggesting that other substances, such as the flavonoids present in this

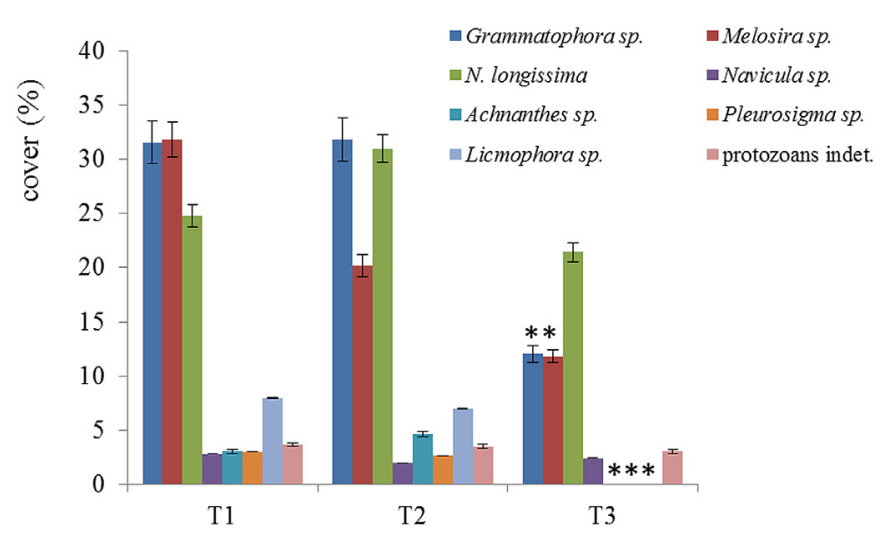

Fig. 5. Microfouling percentage cover on painted panels vs. controls, 45 days exposure (first year). T1: unpainted control, T2: control paint, T3: NOP-paint. Bars = mean $\pm \mathrm{SE}$; *significant differences $(p<0.05)$.

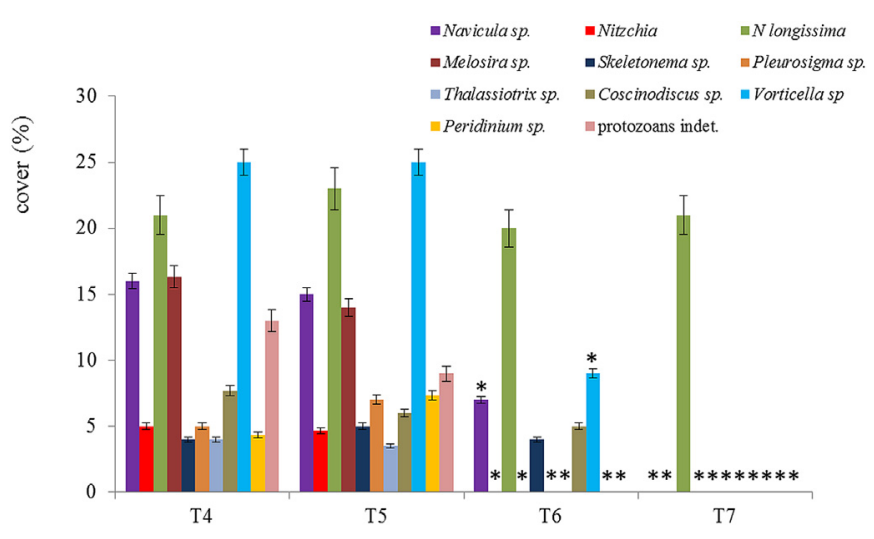

Fig. 7. Microfouling percentage cover on painted panels vs. controls, 45 days exposure (second year). T4: unpainted control, T5: control paint, T6: NOPab-paint, T7: MC-paint. Bars $=$ mean $\pm \mathrm{SE}$; *significant differences from controls $(p<0.05)$. 
acidic fraction may be responsible of the antifouling effect on this particular species. Also, possible interactions and synergism among different compounds should be considered, taking into account that NOPab is still a mixture of different substances, although less complex than the original subextract.

Secochiliolide acid is a diterpenoid that contains an unusual core bearing furan and spiro-lactone fragments. Interestingly, these fragments are common features in some antifouling marine natural products which have been detected in algae, fungi, sponges, and octocorals (Keifer et al., 1986; Clare, 1996, 1998; Clare et al., 1999; Hellio et al., 2005; Shao et al., 2011). For example, furanones inhibit bacterial colonization and biofilm formation through interference with quorum sensing (Steinberg et al., 1997; Lowery et al., 2009). Also, the presence of a furan group deters the settlement and growth of macrofouling organisms and, indirectly affects invertebrate larval attachment by modifying bacterial biofilm density and/or composition (de Nys et al., 2006; Dobretsov et al., 2007; Xu et al., 2010; Li et al., 2013). Furan and lactone rings are also frequent structural motifs in natural products isolated from terrestrial plants and actinomycetes, with properties that may be related to a possible antifouling activity. For example, methyl angolensate, a compound isolated from the Indian plant Soymida febrifuga, has the same structural motifs as secochiliolide acid, and displayed antibacterial, antifungal and insect antifeedant properties (Samir et al., 2001; Chiruvella et al., 2007). Also, benzofurans, furanocoumarins, furoflavones, furanochalcones and furanoterpenes, all of which share with compound $\mathbf{1}$ a furan ring moiety, and can be isolated from terrestrial plants, have shown a broad range of biological activities such as antibacterial and antifungal properties (Sardari et al., 2000; DellaGreca et al., 2001; Waridel et al., 2003; Widelski et al., 2009; Alam and Lee, 2011; Kamal et al., 2011; Tran et al., 2012; Casero et al., 2013). In particular, imperatorin, a furanocoumarin, showed high inhibitory activity against larval settlement of Balanus albicostatus (Wang et al., 2013). Besides, it is well known that many macrocyclic lactones (macrolides) are commercially current antibiotics. Recently, rosinbased coatings loaded with a macrocyclic lactone (ivermectin) were found to be effective in preventing colonization by barnacles (Pinori et al., 2011).

Consequently, it is possible that the presence of furan and/or lactone moieties in secochiliolide acid may be responsible of the displayed antifouling activity. Further experiments will be needed, and suitable derivatives will have to be tested in order to establish the structure-activity relationship of this compound, as well as a determination of the active concentration and other performance and safety parameters. The present work represents the first report of antifouling activity of the organic extract of a Patagonian plant, and an addition of another interesting bioactivity to this fascinating substance. The present results show that, taking into account the availability of the plant source, ease and good yield of purification, and the displayed bioactivity in field trials, secochiliolide acid may be a good natural and sustainable candidate for the replacement of toxic compounds in antifouling paints.

Further experimental investigations will be needed to estimate whether sechiliolide acid affects non target species and how this substance is degraded in the environment. In addition, assessments of the time for retention of the antifouling properties of secochiliolide-based paints will probably have to be made before they can be adopted for its use as efficacious antifouling paints.

\section{Acknowledgments}

This research was supported by a Grant from ANPCYT (PICT 2010-1808), Consejo Nacional de Investigaciones Científicas y Técnicas (CONICET), Comisión de Investigaciones Científicas de la provincia de Buenos Aires (CIC) and Universidad Nacional de La Plata.

We wish to thank the Club de Motonáutica of Mar del Plata for permission to use their marine testing site.

\section{References}

Alam, M., Lee, D., 2011. Cytotoxic and antimicrobial properties of furoflavones and furochalcones. J. Korean Soc. Appl. Biol. Chem. 54, 725-730.

Angarano, M., McMahon, R., Hawkins, D., Schetz, J., 2007. Exploration of structureantifouling relationships of capsaicin-like compounds that inhibit zebra mussel (Dreissena polymorpha) macrofouling. Biofouling 23, 295-305.

Barboza, G., Cantero, J., Núñez, C., Pacciaroni, A., Ariza, L., 2009. Medicinal plants: a general review and a phytochemical and ethnopharmacological screening of the native Argentine flora. Kurtziana 34, 7-365.

Blihoghe, D., Manzo, E., Villela, A., Cutignano, A., Picariello, G., Faimali, M., Fontana, A., 2011. Evaluation of the antifouling properties of 3-alyklpyridine compounds. Biofouling 27, 99-109.

Blustein, G., Pérez, M., García, M., Stupak, M., Cerruti, C., 2009. Reversible effect of potassium sorbate on Balanus amphitrite larvae. Potential use as antifoulant. Biofouling 25, 573-580.

Bonifacino, J., 2005. Nardophyllum cabrerae (Asteraceae: Astereae), a new species from Argentina and new taxonomic changes involving Nardophyllum Hook. Et. Arn. Taxon. 54, 688-692.

Brango Vanegas, J., 2011. Búsqueda de compuestos inhibidores de Quorum Sensing (IQS) a partir de extractos de origen natural. Primera Fase. Tesis. Universidad Nacional de Colombia, Bogotá, Colombia. Facultad de Ciencias, Departamento de Química.

Casero, C., Estévez-Braun, A., Ravelo, A., Demo, M., Méndez-Álvarez, S, Machín, F. 2013. Achyrofuran is an antibacterial agent capable of killing methicillinresistant vancomycin-intermediate Staphylococcus aureus in the nanomolar range. Phytomedicine 20, 133-138.

Chen, J., Feng, D., Yang, Z., Wang, Z., Qiu, Y., Lin, Y., 2008. Antifouling metabolites from the mangrove plant Ceriops tagal. Molecules 13, 212-219.

Chiruvella, K., Mohammed, A., Dampuri, G., Ghanta, R., Raghavan, S., 2007. Phytochemical and antimicrobial studies of methyl angolensate and luteolin-7-0glucoside isolated from callus cultures of Soymida febrifuga. Int. J. Biol. Sci. 3, 269-278.

Clare, A., 1996. Marine natural product antifoulants: status and potential. Biofouling 9, 211-229.

Clare, A., 1998. Towards nontoxic antifouling. J. Mar. Biotechnol. 6, 3-6.

Clare, A., Rittschof, D., Hooper, I., Bonaventura, J., 1999. Antisettlement and narcotic action of analogues of diterpene marine natural product antifoulants from octocorals. Mar. Biotechnol. 1, 427-436.

Da Gama, B., Pereira, R., Carvalho, A., Coutinho, R., Yoneshigue-Valentin, Y., 2002. The effects of seaweed secondary metabolites on biofouling. Biofouling 18, 1320.

de Nys, R., Givskov, M., Kumar, N., Kjelleberg, S., Steinberg, P., 2006. Furanones. Prog. Mol. Subcell. Biol. 42, 55-86.

DellaGreca, M., Florentino, A., Isidoro, M., Monaco, P., Temussi, M., Zarrelli, A., 2001 Antialgal furano-diterpenes from Potamogeton natans L. Phytochemistry 58, 299-304.

Dobretsov, S., Dahms, H.-U., YiLi, H., Wahl, M., Qian, P., 2007. The effect of quorumsensing blockers on the formation of marine microbial communities and larval attachment. FEMS Microbiol. Ecol. 60, 177-188.

D’Almeida, R., Zampini, I., Isla, M., 2007. Phytochemical and biological study of Nardophyllum armatum Wedd. extracts. Boletín Latinoam. del Caribe Plantas Med. Aromáticas 5, 242-243.

D’Almeida, R., Alberto, M., Zampini, I., Ordoñez, R., Isla, M., 2011. Actividad de extractos alcohólicos de Nardophyllum armatum (Wedd.) Reiche (Asteraceae) de dos áreas geográficas de la Puna argentina sobre microorganismos fitopatógenos. Lilloa 48, 17-25.

Etoh, H., Kondoh, T., Noda, R., Singh, I., Sekiwa, Y., Morimitsu, K., Kubota, K., 2002. Shogaols from Zingiber officinale as promising antifouling agents. Biosci. Biotechnol. Biochem. 66, 1748-1750.

Evans, S., 1999. TBT or not TBT?. That is the question. Biofouling 14, 117-129.

Faimali, M., Falugi, F., Gallus, L., Piazza, V., Tagliafierro, G., 2003. Involvement of ACh in settlement process of Balanus amphitrite. Biofouling 19, 213-220.

Feng, D., Ke, C., Lu, C., Li, S., 2009. Herbal plants as a promising source of natural antifoulants: evidence from barnacle settlement inhibition. Biofouling 25, $181-$ 190.

Floerl, O., Pool, T., Inglis, G., 2004. Positive interactions between nonindigenous species facilitate transport by human vectors. Ecol. Appl. 14, 1724-1736.

Floerl, O., Inglis, G., Marsh, H., 2005. Selectivity in vector management: an investigation of the effectiveness of measures used to prevent transport of nonindigenous species. Biol. Invasions 7, 459-475.

Foster, M., Harrold, C., Hardin, D., 1991. Points versus photo quadrat estimates of the cover of sessile marine organisms. J. Exp. Mar. Biol. Ecol. 146, 193-203.

Gavin, N., Durako, M., 2011. Localization and antioxidant capacity of flavonoids from intertidal and subtidal Halophila johnsonii and Halophila decipiens. Aquat. Bot. 95, 242-247. 
Göransson, U., Sjogren, M., Svangard, E., Claeson, P., Bohlin, L., 2004. Reversible antifouling effect of the cyclotide cycloviolacin $\mathrm{O} 2$ against barnacles. J. Nat. Prod. 67, 1287-1290.

Harada, A., Sakata, K., Ina, H., 1985. Isolation and identification of xanthatin as an anti-attaching repellent against blue mussel. Agric. Biol. Chem. 49, 1887-1888.

Hellio, C., Bremer, G., Pons, A., Le Gal, Y., Bourbougnon, N., 2000. Inhibition of the development of microorganisms (bacteria and fungi) by extracts of marine algae from Brittany (France). Appl. Microbiol. Biotechnol. 54, 543-549.

Hellio, C., Tsoukatou, M., Maréchal, J., Aldred, N., Beaupoil, C., Clare, A., Vagias, C., Roussis, V., 2005. Inhibitory effects of Mediterranean sponge extracts and metabolites on larval settlement of the barnacle Balanus amphitrite. Mar. Biotechnol. 7, 297-305.

Hyodo, S., Etoh, H., Yamashita, N., Sakata, K., Ina, K., 1992. Structure of resinosides from Eucalyptus resinifera as repellents against the blue mussel, Mytilus edulis. Biosci. Biotechnol. Biochem. 56, 138.

Iyapparaj, P., Ramasubburayan, R., Raman, T., Das, N., Kumar, P., Palavesam, A., Immanuel, G., 2012. Evidence for the antifouling potentials of marine macroalgae Sargassum wightii. Adv. Nat. Appl. Sci. 6, 153-162.

Jakupovic, J., Banerjee, S., Bohlmann, F., King, R., Robinson, H., 1986. New diterpenes from Chiliotrichium rosmarinifolium and Nardophyllum lanatum. Tetrahedron 42. 1305-1313.

Kamal, M., Shakya, A., Jawaid, T., 2011. Benzofurans: a new profile of biological activities. Int. J. Med. Pharm. Sci. 3, 1-5.

Keifer, P., Reinhart, L., Hooper, I., 1986. Renillafoulings, antifouling diterpenes from the sea pansy Renilla reniformis (Octocorallia). J. Org. Chem. 51, 4450-4454.

Leer-Andersen, M., Larsson, L., 2003. An experimental/numerical approach for evaluating skin friction on fullscale ships with surface roughness. J. Mar. Sci. Technol. 8, 26-36.

Lejars, M., Margaillan, A., Bressy, C., 2012. Fouling release coatings: a nontoxic alternative to biocidal antifouling coatings. Chem. Rev. 112, 4347-4390.

Lewthwaite, J., Molland, A., Thomas, K., 1985. An investigation into the variation of ship skin frictional resistance with fouling. Transact. Royal Inst. Nav. Archit. 127, 269-284.

Li, Y., Wu, H., Xu, Y., Shao, C., Wang, C., Qian, P., 2013. Antifouling activity of secondary metabolites isolated from Chinese Marine organisms. Mar. Biotechnol.. http://dx.doi.org/10.1007/s10126-013-9502-7.

Lin, W., Lu, C., Ye, Y., 2009. Toxicity of crude extracts from several terrestrial plants to barnacle larvae on mangrove seedlings. Ecol. Eng. 35, 502-510.

Lowery, C., Abe, T., Park, J., Eubanks, L., Sawada, D., Kaufmann, G., Janda, K., 2009. Revisiting AI-2 quorum sensing inhibitors: direct comparison of alkyl-DPD analogues and a natural product fimbrolide. J. Am. Chem. Soc. 131, 1558415585.

Maréchal, J., Hellio, C., 2009. Challenges for the development of new non-toxic antifouling solutions. Int. J. Mol. Sci. 10, 4623-4637.

Minchin, D., Gollasch, S., 2003. Fouling and ships' hulls: how changing circumstances and spawning events may result in the spread of toxic species. Biofouling 19, 111-122.

Nguyen, X., Longeon, A., Pham, V., Urvois, F., Bressy, C., Trinh, T., Nguyen, H., Phan, V., Chau, V., Briand, J., Bourguet-Kondracki, M., 2013. Antifouling 26,27cyclosterols from the Vietnamese marine sponge Xestospongia testudinaria. J. Nat. Prod. 76, 1313-1318.

Ovesen, R., Brandt, K., Göransson, U., Nilesen, J., Hansen, H., Cedergreen, N., 2011. Biomedicine in the environment: cyclotides constitute potent natural toxins in plants and soil bacteria. Environ. Toxicol. Chem. 30, 1190-1196.

Pérez, M., García, M., Blustein, G., Stupak, M., 2007. Tannin and tannate from the quebracho tree: an eco-friendly alternative for controlling marine biofouling. Biofouling 23, 151-159.

Pinori, E., Berglin, M., Brive, L., Hulander, M., Dahlström, M., Elwing, H., 2011. Multiseasonal barnacle (Balanus improvisus) protection achieved by trace amounts of a macrocyclic lactone (ivermectin) included in rosin-based coatings. Biofouling 27, 941-953.

Qian, P.-Y., Xu, S., 2012. Antifouling activity of marine natural products. In: Fattorusso, E., Gerwick, W., Taglialatela-Scafati, O. (Eds.), Handbook of Marine Natural Products. Springer Science+Business Media B.V, Dordrecht, Netherlands, pp. 749-816.

Raveendran, T., Limna Mol, V., 2009. Natural product antifoulants. Curr. Sci. 97, 509-520.

Rittschof, D., 2001. Natural product antifoulants and coatings development. In: McClintock, J.B., Baker, B.J. (Eds.), Marine Chemical Ecology. CRC Press, Boca Raton, pp. 543-566.

Samir, A., Abdelgaleil Okamura, H., Iwagawa, T., Sato, A., 2001. Antifeedants from Khaya senegalensis. Tetrahedron 57, 119-126.

Sánchez, M., Mazzuca, M., Veloso, M., Fernández, L., Siless, G., Puricelli, L., Palermo, J., 2010. Cytotoxic terpenoids from Nardophyllum bryoides. Phytochemistry 71, 1395-1399.

Sardari, S., Nishibe, S., Daneshtalab, M., 2000. Coumarins, the bioactive structures with antifungal property. Stud. Nat. Prod. Chem. 23, 335-393.

Sawant, S., Wagh, A., 1994. Studies on the antifouling properties of some natural products from Goa. In: Thompson, M., Nagabhushanam, R., Sarojini, R.,
Fingerman, M. (Eds.), Recent Developments in Biofouling Control. Oxford and IBH Publishing Company, New Delhi, pp. 275-282.

Sawant, S., Wagh, A., 1997. Terrestrial plants: a potential source for isolation of ecofriendly antifouling compounds. In: Proceedings of Emerging Nonmetallic Materials for the Marine Environment, Honolulu, HI, USA

Sawant, S., Sonak, S., Garg, A., 1995. Growth inhibition of fouling bacteria and diatoms by extracts of terrestrial plant, Derris scandens (Dicotyledonae: Leguminocae). Indian J. Mar. Sci. 24, 229-230.

Schultz, M., 2007. Effects of coating roughness and biofouling on ship resistance and powering. Biofouling 23, 331-341.

Schultz, M., Bendick, J., Holm, E., Hertel, W., 2011. Economic impact of biofouling on a naval surface ship. Biofouling 27, 87-98.

Shao, C., Wu, H., Wang, C., Liu, Q., Xu, Y., Wei, M., Qian, P., Gu, Y., Zheng, C., She, Z., Lin, Y., 2011. Potent antifouling resorcylic acid lactones from the gorgonianderived fungus Cochliobolus lunatus. J. Nat. Prod. 74, 629-633.

Shapiro, S., Wilk, M., 1965. An analysis of variance test for normality (complete samples). Biometrika 52, 591-611.

Siless, E., Lozano, E., Sánchez, M., Mazzuca, M., Sosa, A., Palermo, A., 2013. Preparation and antitrypanosomal activity of secochiliolide acid derivatives. Bioorganic Med. Chem. Lett. 23, 4964-4967.

Singh, I., Takahashi, K., Etoh, H., 1996. Potent attachment-inhibiting and -promoting substances for the blue mussel, Mytilus edulis galloprovincialis, from two species of Eucalyptus. Biosci. Biotechnol. Biochem. 60, 1522-1523.

Sjögren, M., Dahlström, M., Hedner, E., Jonsson, R., Vik, A., Gundersen, L.-L Bohlin, L., 2008. Antifouling activity of the sponge metabolite agelasine D and synthesized analogs on Balanus improvisus. Biofouling 24, 251-258.

Steinberg, P., de Nys, R., 2002. Chemical mediation of colonization of seaweed surfaces. J. Phycol. 38, 621-629.

Steinberg, P., Schneider, R., Kjelleberg, S., 1997. Chemical defenses of seaweeds against microbial colonization. Biodegradation 8, 211-220.

Stupak, M., García, M., Pérez, M., 2003. Non-toxic alternative compounds for marine antifouling paints. Int. Biodeterior. Biodegrad. 52, 49-52.

Takasawa, R., Etoh, H., Yagi, A., Sakata, K., Ina, K., 1990. Nonylphenols as promising antifouling agents found by a simple bioassay method using the blue mussel, Mytilus edulis. Agric. Biol. Chem. 54, 1607-1610.

Tan, L., Goh, P., Tripathi, A., Lim, M., Dickinson, G., Lee, S., Teo, S., 2010. Natural antifoulants from the marine cyanobacterium Lyngbya majuscula. Biofouling 26, 685-695.

Thomas, K., Brooks, S., 2010. The environmental fate and effects of antifouling paint biocides. Biofouling 26, 73-88.

Tran, T., Nguyen, T., Do, T., Huynh, T., Tran, C., Thai, K., 2012. Synthesis and antibacterial activity of some heterocyclic chalcone analogues alone and in combination with antibiotics. Molecules 17, 6684-6696.

Tsoukatou, M., Philippe Maréchal, J., Hellio, C., Novaković, I., Tufegdzic, S., Sladić, D. Gasić, M., Clare, A., Vagias, C., Roussis, V., 2007. Evaluation of the activity of the sponge metabolites avarol and avarone and their synthetic derivatives against fouling micro- and macroorganisms. Molecules 12, 1022-1034.

Viju, N., Satheesha, S., Vincenta, S., 2013. Antibiofilm activity of coconut (Cocos nucifera Linn.) husk fibre extract. Saudi J. Biol. Sci. 20, 85-91.

Villa, F., Albanese, D., Giussani, B., Stewart, P., Daffonchio, D., Cappitelli, F., 2010 Hindering biofilm formation with zosteric acid. Biofouling 26, 739-752.

Wang, Z., Feng, D., Ke, C., 2013. Coumarins from the herb Cnidium monnieri and chemically modified derivatives as antifoulants against Balanus albicostatus and Bugula neritina larvae. Int. J. Mol. Sci. 14, 1197-1206.

Waridel, P., Wolfender, J., Lachavanne Hostettmann, K., 2003. ent-Labdane diterpenes from the aquatic plant Potamogeton pectinatus. Phytochemistry 64, 1309-1317.

Widelski, J., Popova, M., Graikou, K., Glowniak, K., Chinou, I., 2009. Coumarins from Angelica lucida L. Antibacterial activities. Molecules 14, 2729-2734.

Xu, Q., Barrios, C., Cutright, T., Newby, B., 2005a. Assessment of antifouling effectiveness of two natural product antifoulants by attachment study with freshwater bacteria. Environ. Sci. Pollut. Res. 12, 278-284.

Xu, Q., Barrios, C., Cutright, T., Newby, B., 2005b. Evaluation of toxicity of capsaicin and zosteric acid and their potential application as antifoulants. Environ. Toxicol. 20, 467-474.

Xu, Y., He, H., Schulz, S., Liu, X., Fusetani, N., Xiong, H., Xiao, X., Qian, P., 2010. Potent antifouling compounds produced by marine Streptomyces. Bioresour. Technol. 101, 1331-1336.

Yamashita, N., Etoh, H., Sakata, K., Ina, H., Ina, K., 1986. New acylated rhaponticin isolated from Eucalyptus rubida as a repellent against the blue mussel Mytilus edulis. Agric. Biol. Chem. 53, 2827-2829.

Yamashita, N., Etoh, H., Sakata, K., Yagi, A., Ina, H., Ina, K., 1989. An acylated kaempferol glucoside isolated from Quercm dentata as a repellent against the blue mussel Mytilus edulis. Agric. Biol. Chem. 35, 1383-1385.

Yoshioka, A., Etoh, H., Yagi, A., Sakata, K., Ina, K., 1990. Isolation of flavonoids and cerebrosides from the bark of Prunus jamasakura as repellents against the blue mussel, Mytilus edulis. Agric. Biol. Chem. 54, 3355-3356.

Zhou, X., Zhang, Z., Xu, Y., Jin, C., He, H., Hao, X., Qian, P., 2009. Flavone and isoflavone derivatives of terrestrial plants as larval settlement inhibitors of the barnacle Balanus amphitrite. Biofouling 25, 69-76. 